\title{
Standpunt
}

\section{Wiskunde- en Wetenskapopleiding op skoolvlak}

Suid-A frika vaar nie goed as ons skoolopleiding in Wiskunde en Wetenskap met die van ander lande vergelyk word nie. Die nou reeds bekende TIMSS-verslag van 1998 het ons heel laaste uit 'n groep lande wat geëvalueer is, geplaas. Daar is wel skole waar dit beter gaan, maar as ' $n$ land in geheel moet ons ernstig bekommerd wees. Dit is nie 'n nuwe probleem nie, maar onlangse verwikkelinge verplig ons om weer aandag hieraan te gee. Die probleem kan uit twee hoeke bekyk word, naamlik 'n kwantitatiewe en 'n kwalitatiewe hoek.

As ons na die getal leerders kyk wat matriek skryf, is die algemene tendens dat die getalle toeneem (360 000 in 1990 tot 551000 in 1998) maar die getal leerders wat matrikulasievrystelling verwerf, neem nie in dieselfde mate toe nie (60300 in 1990 tot 71700 in 1998). Slegs ongeveer 'n derde van die leerders met matrikulasievrystelling het Wiskunde geslaag en die verhouding is besig om af te neem. Dit is veral ' $n$ probleem by swart leerders. ' $n$ Verdere ontstellende tendens is dat die totale getal leerders wat Wiskunde in die Hoërgraad geslaag het, besig is om in absolute terme af te neem tot so laag as 20000 in 1998.

Wiskunde en Wetenskap is nie gewilde vakke op skool nie en ander lande. selfs ontwikkelde Westerse lande, rapporteer ' $n$ soortgelyke tendens. In ons geval is die basis waarvandaan hierdie afiname plaasvind egter só laag dat ons dit nie durf aanvaar nie.

Al die tersiêre inrigtings dui in hulle Driejaarplanne wat aan die Departement van Onderwys gelewer is aan dat hulle beplan om die getal studente in die natuurwetenskappe te laat toeneem. Dit lyk egter nie of daar voldoende matrikulante is om so 'n groei toe te laat sonder om toelatingstandaarde betekenisvol te verlaag nie.

Wat kwaliteit betref, is daar ook ' $n$ afwaartse neiging. Die feit dat die getal leerlinge wat Wiskunde en Wetenskap met onderskeiding slaag jaarliks toeneem, is juis nie gerusstellend nie. Hierbenewens rapporteer dosente dat eerstejaarstudente al hoe meer sukkel om universiteitstandaarde in eerstejaarkursusse in Wiskunde en Chemie/Fisika te hanteer.

Soos verwag kan word, makk universiteite planne om die impak van hierdie tendense op die universiteit te probeer teëwerk. 'n Korttermynstrategie van universiteite is om werwingspogings wat op die krimpende getal potensiële studente gemik is, te intensifeer. Dit is dan ook waarom ons vir die eerste keer in ons geskiedenis grootskaalse advertensieveldtogte deur universiteite in die openbare pers, radio-, televisie- en rolprentbedrywe ervaar.

Die toenemende onbetroubaarheid van matriekuitslae verplig universiteite om hulle eie toelatingstoetse te ontwikkel. Hierdie toetse het aanvanklik sterk op die evaluering van die potensiaal van die leerling gekonsentreer. Dit is egter nie voldoende nie en deesdae word al hoe meer aandag gegee aan die werklike verstaan en kennis van die voornemende studente in Wiskunde en Wetenskap.

Die meeste universiteite het ook spesiale ondersteuningsprogramme wat daarop gemik is om die relatiewe klein groepie addisionele studente wat by sulke programme kan baat in die hoofstroom natuurwetenskaplike opleiding te probeer inkry. Universiteite moet hiermee egter versigtig wees, want om studente toe te laat wat nie oor die vermoëns of die vaardighede beskik om 'n universiteitsprogram suksesvol te kan voltooi nie, is moeilikheid soek. Universiteite moet die druk (finansieel en polities) weerstaan, want niemand - nie eens die studente wat so toegelaat word - baat daarby nie.

'n Groot aantal van die studente wat spesiale programme volg se taalgebruik en kommunikasievaardighede is ontstellend laag. Taalvaardigheidstoetse dui daarop dat slegs ongeveer $30 \%$ van die studente wat wel matrikulasievrystelling het, oor voldoende taalvaardigheid beskik om ' $n$ eerstejaarlesing te kan volg en ' $n$ skriftelike werkstuk te kan voorberei. Dit is veral studente wat hierdie kommunikasie in hulle tweede taal moet doen wat baie sukkel. Hierbenewens het die meeste universiteite ook uitreikprogramme om onderwysers te help om die kwaliteit van opleiding op skool te probeer verbeter.

Daar is duidelik fout by ons skole. Die probleem is heelwat groter as die universiteite se vermoë om aandag daaraan te gee. Die Danish International Development Agency se studie wat in 1997 gepubliseer is, Mathemalics and Science Teachers: demand. utilization, supply and training in South Africa, wys ook uit dat ons huidige opleidingstelsel nie in staat is om Wiskunde- en Wetenskap-onderwysers in voldoende getalle en van aanvaarbare kwaliteit op te lei nie. Die onderwyskolleges, veral die wat nie een of ander assosiasie met 'n universiteit het nie, se kwaliteit word erg bevraagteken. Dit is veral verontrustend dat die aantal nuwe onderwysers met Wiskunde en Wetenskap wat elke jaar nuut tot die onderwys toetree, nie eers genoeg is om die gewone omset in hierdie onderwyserskorps te vervang nie.

Opsommend kan gesê word dat daar te min matrikulante is met 'n aanvaarbare vlak van opleiding in Wiskunde en Wetenskap om tersiêre inrigtings te voorsien van studente wat op hulle beurt weer moet voorsien in die mark vir opgeleide natuurwetenskaplikes. Daar is ook nie voldoende onderwysers wat goed genoeg opgelei is om die situasie reg te stel nie. Hierdie saak word verder gekompliseer deur die effek van regstellende aksie op die bestaande onderwyserskorps.

Sonder ingrypende aksies deur almal wat betrokke is, sal die situasie nie vanself verbeter nie. Trouens, dit is besig om te versleg.

Tersiêre inrigtings word tans al hoe meer ingedwing in 'n situasie waar hulle verantwoordelikheid moet aanvaar vir die regstelling van dit wat nie op skool gebeur het nie. Al hoe meer oorbruggings- en ondersteuningskursusse moet aangebied word. Dit is duidelik nie 'n haalbare strategie nie.

Al werklike langtermynoplossing is om meer en beter opgeleide en gemotiveerde onderwysers voor die klasse te kry. Dit is op hierdie vlak waar universiteite wel betrokke moet word. Die inkorporering van onderwyskolleges by universiteite is ' $n$ belangrike stap in hierdie rigting. Indiensopleiding van die bestaande onderwyserskorps deur middel van telematiese onderrig word reeds gedoen en sal uitgebrei moet word. Hierdie beter opgeleide onderwysers sal egter nie sonder ander ondersteuning die wa deur die drif kan trek nie. Die hele onderwyssisteem moet ook aandag kry.

Dit is daarom bevredigend dat Minister Kader Asmal se oproep vroeër vanjaar vir 'n "call to action" dit duidelik stel dat die Regering bewus is van die erns van die saak. Dit lui soos volg:

In crucial respects we are not ready for the 21 st century.

... Over-whelmingly, poor learning is associated with 
poverty, bad or absent facilities, underprepared teachers, lack of learning resources, and a serious lack of purpose and discipline in many schools, or what is called a culture of learning, teaching and service.

The number of young people who study mathematics with any degree of understanding and proficiency has declined when it should have been increasing rapidly. As a result mathematical illiteracy is rife in our society, and the pool of recruits for further and higher education in the information and science-based professions is shrinking, a fact that has grave implications for our national future in the 2 I st century.

Dit wil voorkom asof die Regering ook al by die stadium verby is waar die probleme net bestudeer word. Die Minister se oproep "call to action" is nou opgevolg met 'n besprekingsdokument: Science, Techology. Engineering and Mathematics Edacation (STK1//E) Stralegy (Oktober 1999). Hierdie pogings verdien almal se steun, want as dit nie slaag nie, sak ons net verder terug, en hoe laer die basis is waarvandaan ons dan moet opbou, hoe moeiliker en langer word die proses.

Befondsing van hierdie opbou-inisiatiewe is natuurlik 'n probleem op sy eie. Dit is nie realisties om te verwag dat die Regering meer as die huidige $21 \%$ van die begroting aan onderwys bestee nie. ' $n$ Totale herskikking van die bestedingspatrone in die onderwysbegroting is noodsaaklik. Die mees voor die hand liggende stap is om die aantal tersiêre inrigtings te rasionaliseer ten einde die koste per student te verminder. Dit kan fondse vrystel wat spesifiek geoormerk moet word vir Wiskunde- en Wetenskapopleiding op skool. Die aanname hier is dat die skole ook beter bestuur sal word, want on net meer fondse na swak bestuurde skole te kanaliseer, is ' $n$ mors van geld.

So 'n rasionalisasie van tersiêre inrigtings mag impliseer dat Suid-Afrika ' $n$ laer persentasie jong mense in die 18 tot 21 -jarige ouderdomsgroep in voltydse tersiêre opleiding sal hê as dit vergelyk word met die ontwikkelende lande. Dit is egter die prys wat ons sal moet betaal as ons skole op standaard wil kry. Dit help nie ons spandeer die geld aan tersiêre inrigtings terwyl die skoolstelsel in duie stort nie. Ons moet doodeenvoudig net die bose kringloop van swak onderwysers en swak voorbereide studente breek as ons ons tersiêre inrigtings in staat wil stel om kwaliteitsopleiding te kan aanbied.

\section{T. ERASMUS}

Viserektor

Universiteit van Pretoria 